\title{
Reprocessing of mining waste: combining environmental management and metal recovery?
}

G. Bellenfant Mine Safety and Risk Prevention Department, BRGM, France

A.G. Guezennec Water, Environment and Ecotechnology Division, BRGM, France

F. Bodenan Water, Environment and Ecotechnology Division, BRGM, France

P. D'Hugues Water, Environment and Ecotechnology Division, BRGM, France

D. Cassard Geo Resources Division, BRGM, France

\begin{abstract}
Raw materials are essential for the sustainable functioning of modern societies. Access to and affordability of mineral raw materials are crucial for the sound functioning of the European Union's economy. The increasing demand for raw materials raises growing concerns regarding mineral resources and especially metals availability. Furthermore, many metals, metalloids or rare earth elements that had no application in the past are now used for the manufacture of high added-value products, especially in the domain of new and green technologies. Many of them are by-products of base metals production, and their reserves are very limited. Therefore a list of strategic and critical materials was established by the European Commission in 2010. Following the rich mining history of France, there are currently some 300 mineral deposits mined or significantly explored. These are the source of large quantities of 'tailings' (gangue, processing waste resulting from concentration or hydrometallurgical treatment, slag, heap).
\end{abstract}

The European Directive 2006/21/EC of 15 March 2006 on the management of waste from extractive industries oversees the permit conditions, storage, monitoring and control of mining waste to ensure the protection of human health and the environment. The member states have to carry out and periodically update an inventory of closed waste facilities that cause or have the potential to cause a serious threat to human health or the environment. Moreover, the directive encourages the recovery of extractive waste by means of recycling, reuse or reclamation. Following this, an inventory was finalised in France in 2012 in which 2,100 metallic and 1,300 coal tailings were identified and prioritised according to their potential impacts on groundwaters, surface waters, soils and human health. Among these, 53 sites with major environmental issues were listed. These sites are and will be the subject of specific actions (environmental and sanitary studies, works of rehabilitation) in order to reduce their long-term impact on both human health and environment. While metallic elements present in the tailings are by nature nondegradable, these actions require long-term approaches.

The paper focuses on one of these sites, former $\mathrm{Pb}$-Ag mines, where operations have led to the production of 200,000 $\mathrm{m}^{3}$ of mining waste. A French Geological Survey (BRGM) rehabilitation programme, based on environmental studies, was designed to stop additional tailings erosion towards the river and the surrounding areas and to avoid any contacts between the contaminated materials and the population. Metals recovery could be envisaged to mitigate the remediation cost.

Indeed, old waste deposits related to past mining and metallurgical activities can be considered as significant reserves of valuable metals because the latter were not exploited or because economically recoverable metals may remain. In France, a recently started project handled by BRGM is aimed at identifying interesting old mining wastes deposits at the national level and assessing the metal recovery potential of these dumps. In a first step, it focuses on previous sites to be rehabilitated. The objective is to develop a methodology combining mining wastes environmental management and economic valorisation in a long-term perspective. 


\section{$1 \quad$ Introduction}

Raw materials are essential for the sustainable functioning of modern societies. Access to and affordability of mineral raw materials is crucial for the sound functioning of the European Union's (EU's) economy.

The EU still has valuable deposits and much underexplored and unexplored geological potential, but their exploration and extraction face increased competition from different land uses and is required to take place in a highly regulated environment. With only $3 \%$ of the world's ore production and $25-30 \%$ of the world's metal consumption, Europe is highly dependent on imports for many raw materials. Indeed, the international context regarding mineral resources and demand is complicated by the fact that many metals, metalloids or rare earth elements that did not have any application in the past are now critical elements for the manufacture of high added-value products, especially in the domain of information, communication and green technologies (Figure 1). For example, new low-carbon technologies like wind turbines, electric cars, energy-saving light bulbs, fuel cells and catalytic converters require rare and precious metals for their production. Many of them are by-products of base metals production (Figure 2).

These materials are increasingly affected by growing demand pressure from emerging economies and by an increasing number of national policy measures that disrupt the normal operation of global markets.

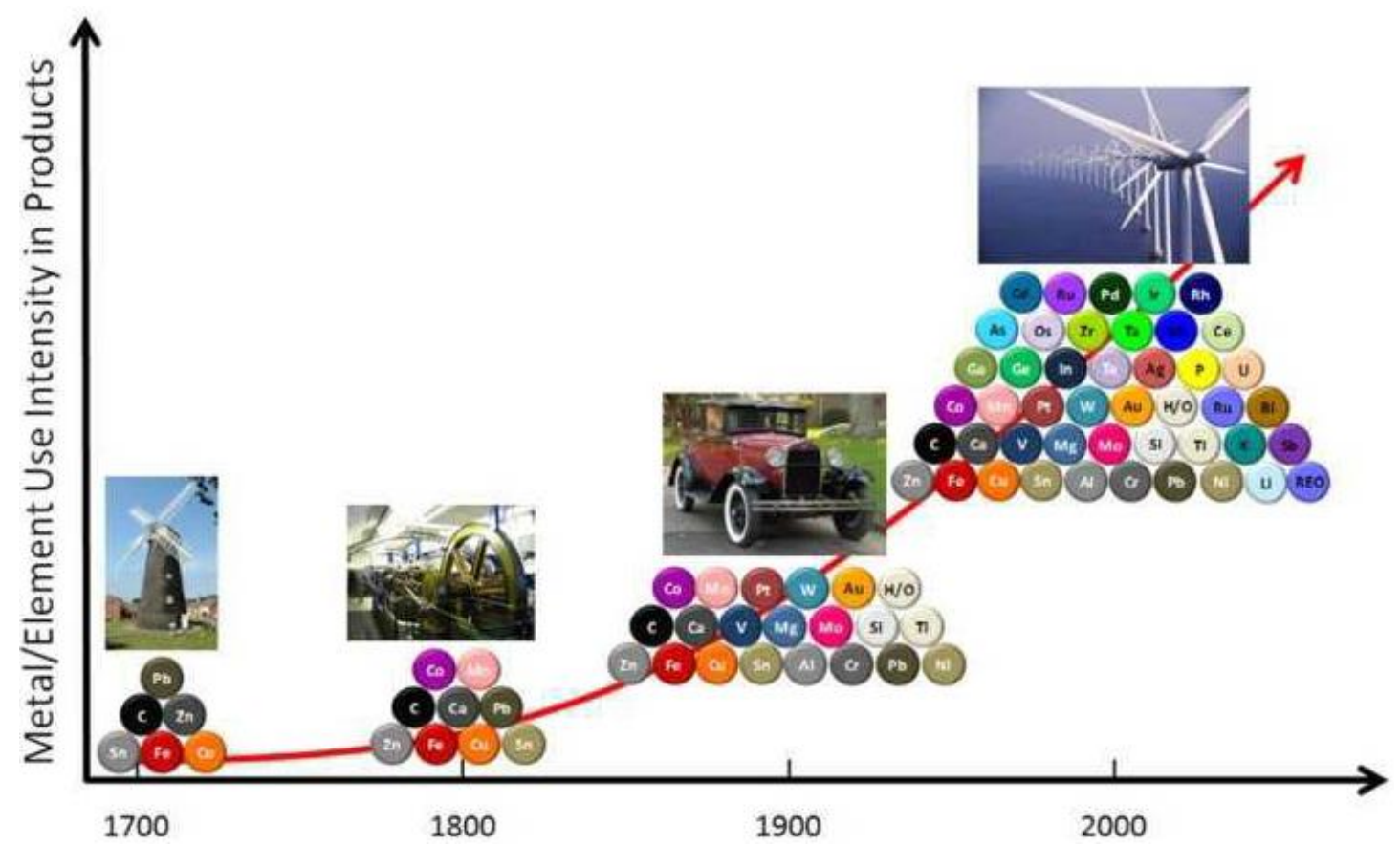

Figure 1 Evolution of metal and element use along time in industry 

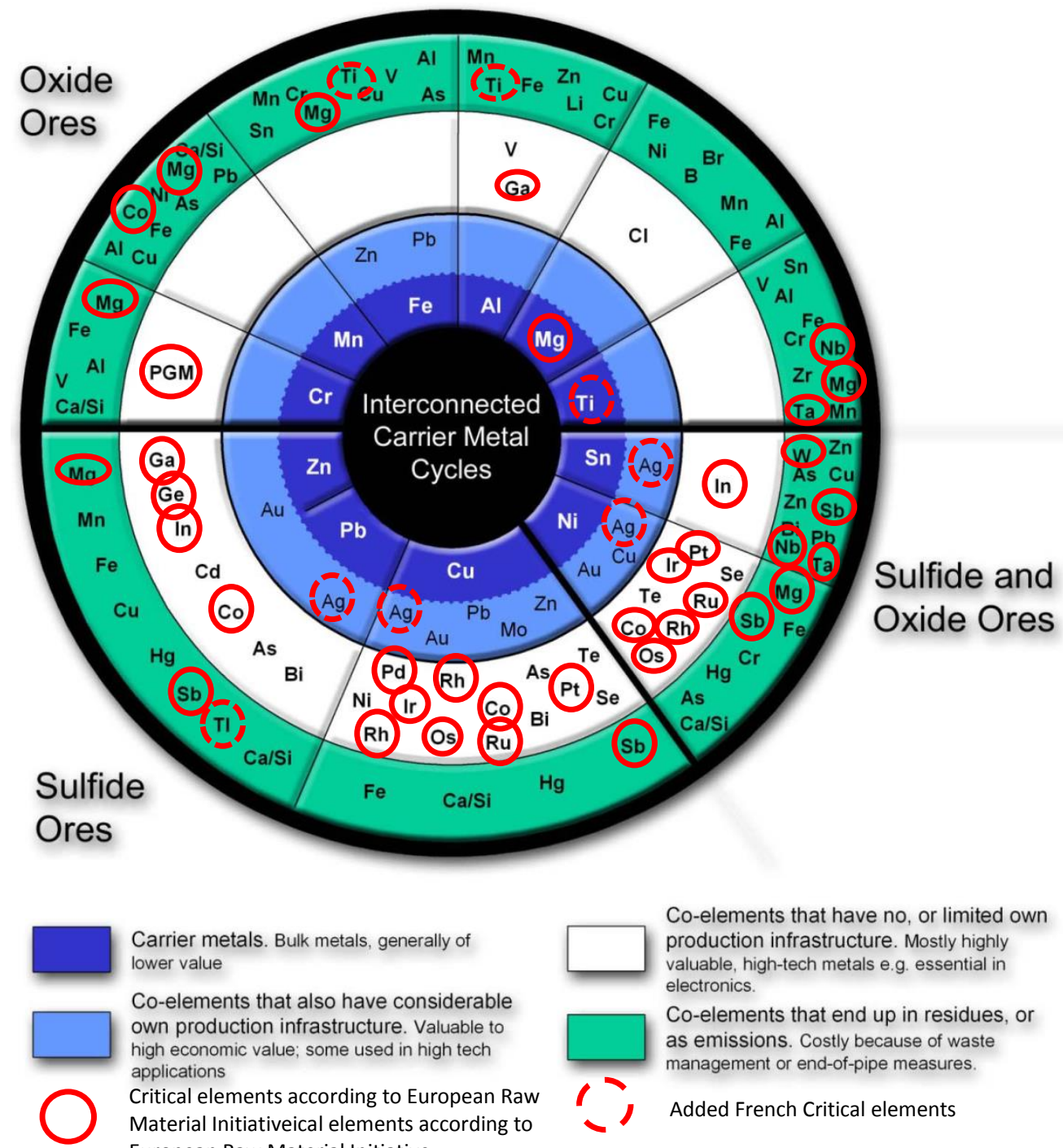

Carrier metals. Bulk metals, generally of lower value

Co-elements that also have considerable own production infrastructure. Valuable to high economic value; some used in high tech applications

Critical elements according to European Raw

Material Initiativeical elements according to

Co-elements that have no, or limited own production infrastructure. Mostly highly valuable, high-tech metals e.g. essential in electronics.

Figure 2 Relationship between the main 'carrier' metals and the associated co-product metals (from Reuter et al. 2005); the 'metals circle' shows the occurrence of minor and critical metals with the primary carrier metal ores

The European Raw Materials Initiative was published in November 2008 as an integrated Strategy to (1) secure sustainable access from outside Europe, (2) improve framework conditions for extracting minerals within Europe and (3) promote the recycling and resource efficiency of such materials. A list of 14 critical materials was established by the European Commission in 2010 (antimony - Sb, beryllium - Be, cobalt - Co, fluorspar, gallium - Ga, germanium - Ge, graphite, indium - In, magnesium - $\mathrm{Mg}$, niobium - $\mathrm{Nb}$, platinum group metals $-\mathrm{PGMs}$, rare earths $-\mathrm{RE}$, tantalum - Ta and tungsten $-\mathrm{W}$ ) according to the following criteria:

- Economic importance.

- Supply risk (stability/instability and level of concentration of producing countries, substitutability, recycling, aggregation).

- Environmental country risk.

Taking into account the specificities of the French industrial context, silver and titanium have been added to the European list. It is important to note that in many cases a significant proportion of primary global resources of the critical metals are hosted in poly-metallic deposits. That is, these critical metals commonly do not occur on their own but along with other metals. In addition, the critical metals are usually not the major commodity occurring in the deposits and are considered as by-products of the main carrier metals. 
For example poly-metallic copper, nickel, zinc and lead resources will likely be accompanied by several of the critical metals.

\section{$2 \quad$ Mining waste context}

\subsection{Definition}

Mining waste can be defined as a part of the materials that result from the exploration, mining and processing of substances governed by legislation on mines and quarries. The term 'mining wastes' regroups in reality different products resulting from the extractive industry. Waste rocks consist of non-mineralised and low-grade mineralised rock removed from, around or within the orebody during extraction activities. The cut-off grade that differentiates low-grade waste rock from useable ore is an economic distinction and may vary over time. Processing waste or tailings are the waste solids or slurries that remain after the treatment of minerals by separation processes (e.g., crushing, grinding, size-sorting, flotation and other physico-chemical techniques) to remove the valuable minerals from the less valuable rock. More specifically, slags are residues from the smelting pyrometallurgical process.

These have to be differentiated from the overburden, which corresponds to the surface material (topsoil, rock) removed during surface mining operations to expose the ore beneath.

\subsection{Quantities in Europe and France}

According to Eurostat estimations (Eurostat, 2010), mining and quarrying wastes accounted for more than 720 million tonnes in 2010, corresponding to $28 \%$ of the total waste production in Europe (27 countries), and for 1 million tonnes in France.

It is difficult to obtain precise numbers concerning historical mining wastes. Except for the Promine databases, to be discussed, no Europe-wide database exists to date on the location and the physical and chemical characteristics of mining waste and other industrial deposits. Following the rich mining history of France, there are currently more than $\mathbf{3 0 0}$ mineral deposits mined or significantly explored. These are the source of large quantities of mining wastes. According to a study carried out by the French Geological Survey (BRGM, 1997), 130 million of tonnes of non-ferrous mining wastes exist in France. And according to a European study carried out by BRGM (BRGM, 2001), 1.2 billion tonnes of tailings (see definition below) were estimated in Europe (12 countries), with 78 million tonnes in France. These numbers need to be put in perspective, as they were obtained with questionnaires and based on ore production.

More recently, as a result of the European Directive inventory finalised in France in 2012, some 2,100 metallic and 1,300 coal tailings were identified and prioritised according to their potential impact on groundwaters, surface waters, soils and human health. Among these, 53 sites with major environmental issues were listed. These sites are and will be the subject of specific actions (environmental and sanitary studies, works of rehabilitation) in order to reduce their long-term impact on both human health and environment. Metallic elements present in the tailings being by nature non-degradable, these actions require long-term approaches.

\subsection{Environmental impacts of mining wastes}

Solid mining wastes are stored in piles or in tailings impoundments around or near mine sites. These storage facilities allow for the physical containment of the mining waste but they cannot completely prevent environmental problems. Air and soil can be contaminated by the generation and dispersal of dust, and groundwater and surface water can be contaminated by seepage through embankments or through the base of the tailings pile. In summary, these wastes can affect the environment through one or more of the following intrinsic criteria:

- Chemical and mineralogical composition.

- Physical properties. 
- Volume and surface occupied.

- Waste disposal method.

They typically contain large fractions of sulphide material that is vulnerable to alteration as it comes into contact with air and meteoric water. In the absence of sufficient neutralising minerals such as calcium carbonates (Juillot et al., 1999), acid mine drainage (AMD) - also called acid rock drainage - is generated. A worldwide estimate assumes that about $20,000 \mathrm{~km}$ of river and 70,000 ha of lake and reservoir areas are seriously damaged by acidic mine effluent (Johnson and Hallberg, 2005). The control and mitigation of AMD mining wastes alone is considered to be one of the major environmental challenges facing the mining industry worldwide (International Network for Acid Prevention, 2011). This is evidenced by sites such as the Rio Tinto estuary in Spain, where surface water contamination is still present from historic mining as much as 4,500 years ago (Leblanc et al., 2000).

Most dramatically, tailings dams can fail. Since 1970, over 70 major failures of impoundments have occurred around the world. Many of these have resulted in short- and long-term damage to ecosystems, in significant impact on communities and, most seriously, in the loss of over 1000 lives (Blight, 2010; Fourie, 2009). The Aznalcóllar-Los Frailes dam failure in 1998 (Grimalt et al., 1999) is unfortunately well known and led to the discharge of 4.5 million cubic meters of toxic tailings slurries into surface water (Achterberg et al., 1999); the rehabilitation has cost approximately $€ 250$ million.

\section{$2.4 \quad$ Regulation context}

The 2006/21/EC European Directive on the management of waste from extractive industries oversees the permit conditions, storage, monitoring and control of mining waste. The purpose is to ensure the protection of human health and the environment. The member states have the obligation to carry it out by 2012 and to periodically update an inventory of closed waste facilities. The directive encourages the recovery of extractive waste by means of recycling, reuse or reclamation.

Moreover, in January 2012 the Consultative Commission on Industrial Change on the processing and exploitation of industrial and mining waste deposits in the European Union made several observations and proposals:

- No Europe-wide database exists to date on the location and the physical and chemical characteristics of mining waste and other industrial deposits.

- The commission suggests reassessing the economic potential of waste resulting from old industrial activities and making this domain environmentally sound.

- It also suggests stimulating research and innovation on technology for reworking and rehabilitating old overburdened waste repositories. The European Innovation Partnership on Raw Materials could provide a vehicle to stimulate research in this area and possibly provide funding for pilot projects.

Providing long-term access to the available mineral resources therefore requires more focus on sustainable mining, on research for environmentally sound mining and processing technology as well as on the social and economic aspects of mining. To counteract the steady increase in global demand for primary mineral resources and to reduce the negative social and environmental impacts associated with meeting this demand, it is necessary to increase material efficiency in manufacturing processes, to search for new substitute raw materials and to recycle materials more widely and more effectively through technological innovations. Reprocessing of mining wastes, prioritising those with acute environmental impacts, is a way to improve metal recovery while protecting human health and the environment.

The following sections present an example of a mining waste rehabilitation project. 


\section{$3 \quad$ From a classic rehabilitation towards a global environmental management}

\subsection{Site presentation}

In Auvergne, vein deposits of argentiferous galena, sphalerite and pyrite with arsenic were mined so that Pontgibaud was one of the largest mining and metallurgical districts in Europe for lead in the nineteenth century. Some 50,000 tonnes of lead and 100 tonnes of silver were produced up through 1905, when the metallurgy ended.

The legacy of the mining activity consists of:

- $70 \mathrm{~km}$ of galleries and 3,000 m of mine shaft (Gallo-Roman period and the nineteenth century).

- 30 adits and 20 mineshafts.

- Four areas of waste rocks and tailings sites.

The mining wastes are constituted of rock wastes, tailings and slags. The total volume of mining waste is around $200,000 \mathrm{~m}^{3}$, distributed as follow:

- Site 1: $78,000 \mathrm{~m}^{3}$ over $23,000 \mathrm{~m}^{2}$.

- Site 2: $87,000 \mathrm{~m}^{3}$ over $45,000 \mathrm{~m}^{2}$.

- Site 3: $33,000 \mathrm{~m}^{3}$ over $8,800 \mathrm{~m}^{2}$.

- Site $4: 4,000 \mathrm{~m}^{3}$ over $4,800 \mathrm{~m}^{2}$.

The four sites are located along the Sioule River. Since no vegetation grew on the tailings, they are subject to erosion by rainfall and wind. As a consequence, they impact the river sediments and the surrounding areas.

\subsection{The project of rehabilitation}

First, all the 50 adits and shafts were closed by BRGM in 2009. The operation established by the French state was performed in order to avoid any risks such as a deliberate or accidental entry, ground instability due to the opening or the circulation of fluids (water or gas). The treatment solutions included a backfilling and closure with a self-supporting plug for the mineshaft and for the adit closures, while keeping a specially adapted opening for bats and snakes.

Second, an environmental study was carried out, according to a source-pathway-target methodology, to bring out the potential impacts of the four mining waste sites on humans and the environment. The study focused on:

- Source evaluation (volumes, heavy metal content, etc.).

- Groundwater.

- Surface water, including sediments.

- Sensitivity of the surrounding environment (threatened or vulnerable species according to Natura 2000, groundwater and surface water uses, etc.).

- Uncontrolled reuse of tailings by local population.

- Site uses.

The tailings contain high concentrations of lead (between 6 and $70 \mathrm{~g} / \mathrm{kg}$ ), arsenic $(0.9$ to $8 \mathrm{~g} / \mathrm{kg}$ ), cadmium (4 to $107 \mathrm{mg} / \mathrm{kg}$ ), zinc ( 0.8 and $2.3 \mathrm{mg} / \mathrm{kg}$ ) and chromium (0.01 to $0.1 \%$ ), and concentrations locally can 
reach $8 \%$ for lead, $1.5 \%$ for zinc and $0.9 \%$ for arsenic. These elements are environmentally undesirable or dangerous to human health.

The sediments are clearly impacted. The geochemical background is estimated at $90 \mathrm{mg} / \mathrm{kg}$ and $74 \mathrm{mg} / \mathrm{kg}$ for arsenic and lead, respectively. Concentrations immediately downstream of the sites are between 300 and $740 \mathrm{mg} / \mathrm{kg}$ for arsenic and between 4,000 and $11,000 \mathrm{mg} / \mathrm{kg}$ for lead. Further downstream, concentrations are between 100 and $130 \mathrm{mg} / \mathrm{kg}$ and between 400 and $1000 \mathrm{mg} / \mathrm{kg}$ respectively for As and $\mathrm{Pb}$.

The impacts on Sioule River are measurable but low due to the dilution and the absence of AMD (the presence of basalts and probably because a large part of the sulphides are already oxidised). The geochemical background for $\mathrm{As}$ and $\mathrm{Pb}$ is $3 \mu \mathrm{g} / \mathrm{l}$ and $0.5 \mu \mathrm{g} / \mathrm{l}$ respectively, and the analyses show the following concentration:

- Immediately downstream: $7 \mu \mathrm{g} / \mathrm{I}$ for As and $16 \mu \mathrm{g} / \mathrm{l}$ for $\mathrm{Pb}$.

- Further downstream: $5 \mu \mathrm{g} / \mathrm{l}$ for As and $1.5 \mu \mathrm{g} / \mathrm{l}$ for $\mathrm{Pb}$.

The aquifer located below the site flows through volcanic slag and ash layers deposed between layers of basalt and no groundwater impact was identified.

Different activities leading to a direct contact between human beings and the mining waste were identified (such as mountain biking, practice of motorcycle, etc.).

These impacts are synthetised in the following conceptual scheme, focusing on site 2 (Figure 3).

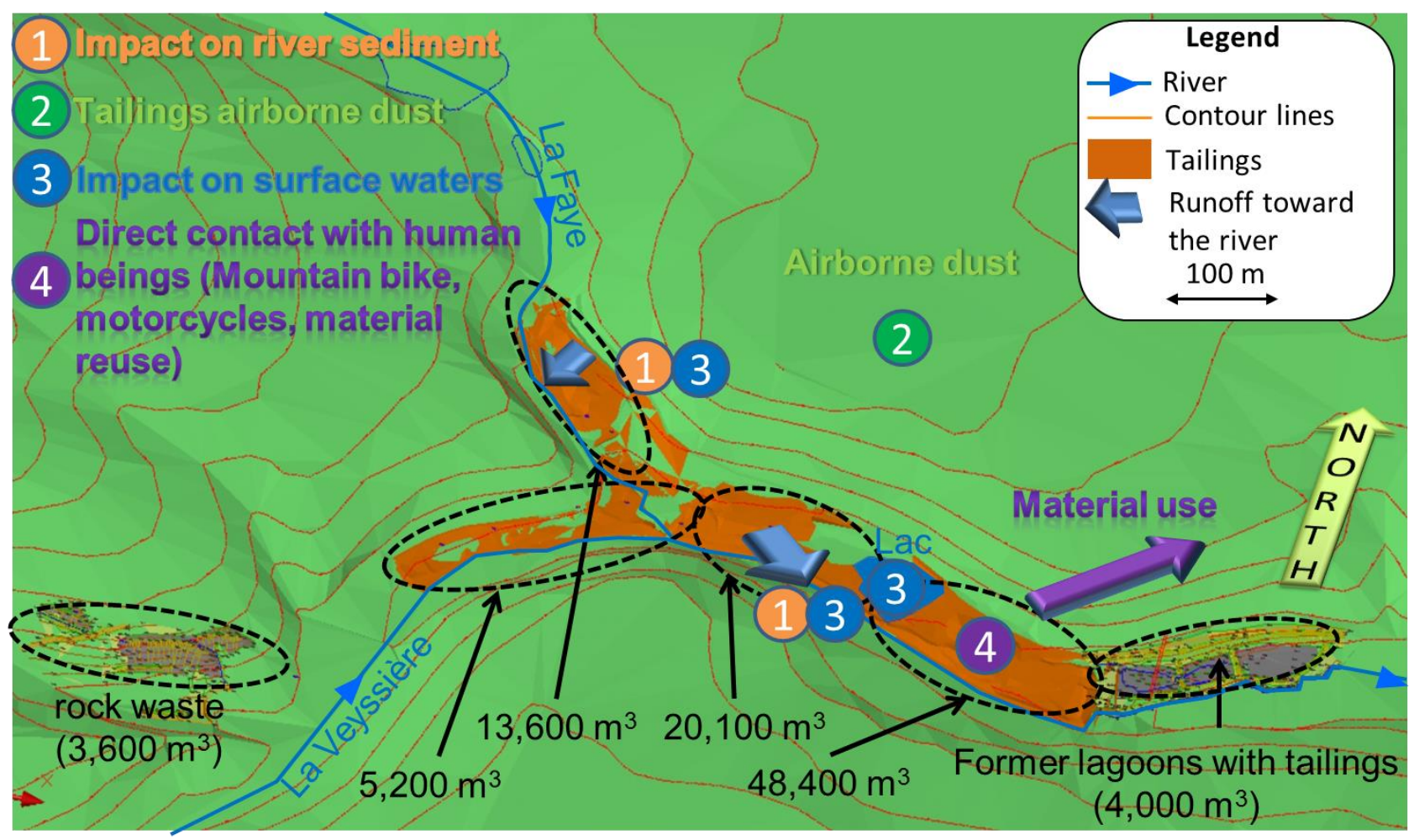

\section{Figure 3 Conceptual scheme of site 2 impacts}

Following these results, a rehabilitation programme was designed to stop additional tailings erosion towards the river and the surrounding areas and to avoid any contacts between the contaminated materials and the population.

A flora and fauna study is ongoing to characterise the sites' impacts according to Natura 2000 regulation. It is used to guide the rehabilitation design so that the sites' residual impacts will be reduced as much as possible. The flora and fauna study recommendations include the rehabilitation works period. 
The rehabilitation works will include several operations:

- Tailing and rock waste earthworks to reduce the mining wastes' footprint and to obtain final slopes reducing the rainfall infiltration while reducing erosion.

- The implementation of a $80 \mathrm{~cm}$ thick topsoil with amendment if necessary.

- Revegetation with local species, allowing for long-term protection of the cover against erosion.

- Surface water management works (trenches, drainage).

Figure 4 illustrates the conceptual scheme of the works planned on site 2 . In this case, in addition to the operation described previously, the rehabilitation programme will include the restoration of former lagoons to implement a wetland. This wetland area, collecting all the waters drained from the tailing via drainage groins, will help reduce the metal load towards the river.

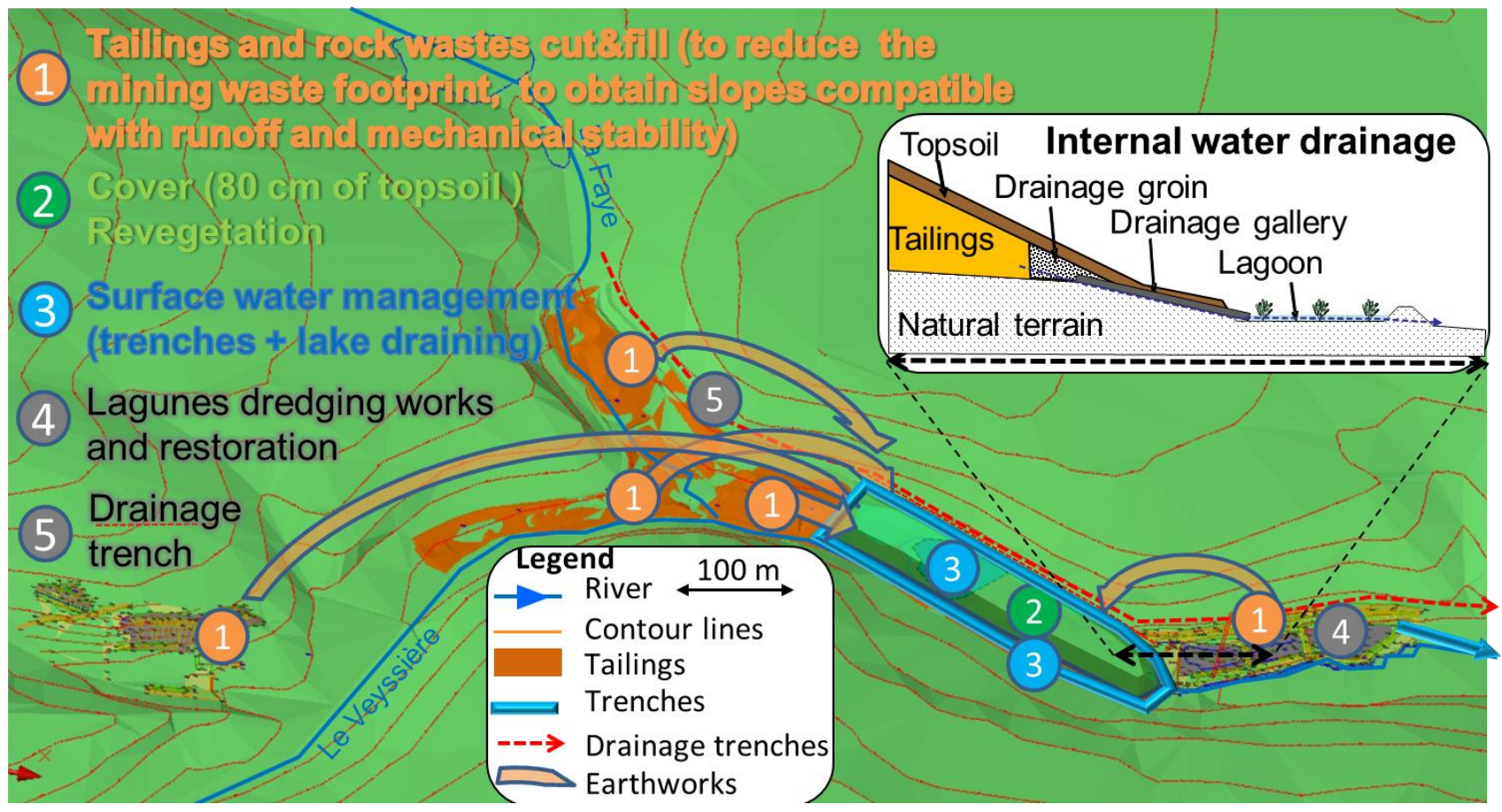

\section{Figure 4 Conceptual scheme of site 2 rehabilitation works}

The cover design is the key point of the rehabilitation programme, as it is the only barrier to avoid contact and spreading of the mining wastes towards the environment. The main difficulty is due to the timescale, as the metal pollutants are by nature non-degradable. As a consequence, the cover must last for the long term, and the only way to succeed involves the durability of the vegetation. The plant species will be selected according to the recommendation of the fauna and flora study, and a programme will be necessary to monitor the evolution of the plants' distribution over time.

Studies should be carried out to investigate the influence of the organic input (organic amendment in the topsoil and organic input due to development of the vegetation) on the evolution of the bioavailability of the metals present in the mining waste.

Site 2 rehabilitation works are estimated to cost $€ 950,000$, with the largest items of expenditure being the mining wastes cut-and-fill works and the cover implementation $\left(20,000 \mathrm{~m}^{2}\right)$. Considering the $95,000 \mathrm{~m}^{3}$ of mining waste (tailing and rock wastes), the unit cost of the rehabilitation is $€ 10$ per cubic meter.

Given the volume of mining wastes all over France and Europe, a global rehabilitation programme seems difficult to envisage because of the cost, which will be generally supported by the community. One ought to consider a prioritisation in the site rehabilitations, for example based on the national inventories of mining 
wastes requested by the European Union. Given the possible presence of strategic elements in the mining waste, it is relevant to include the economic potential of their recovery in the global rehabilitation strategy.

\subsection{A research project regarding metal recovery}

Given the evolution of the context regarding mineral resources and the necessity to recycle, old waste deposits related to past mining and metallurgical activities can be considered as significant reserves of valuable metals because they were not exploited or because economically recoverable metals may remain. But site documentation is rare, and applicable methodology to recover these metals is not so well defined.

In the 1990s, a bioleaching process was used to recover cobalt in Uganda from pyritic wastes previously accumulated during the exploitation of a copper mine (Morin et al., 1993; Morin, 1997). In 2005, a study (Goktepe, 2005) related the recovery of lead from lead-zinc mining wastes using a multi-gravity separator. Peek et al. (2011) focused on nickeliferous pyrrhotite tailings containing $0.8 \%$ of nickel. Fosso-Kankeu et al. (2011) tested the biological recovery of nickel from tailing. In Germany, Kamradt et al. (2012) studied the recovery of $\mathrm{Cu}$ and $\mathrm{Ag}$. A recently started project in central Sweden identified many mineralisations and deposits in this region, the majority of them being associated with mine dumps with high average rare earth elements contents (Högdahl et al., 2012).

In France, a recently started project VALODEM handled by the French geological survey (BRGM) is aimed at identifying interesting old mining wastes deposits at the national level and assessing the metal recovery potential of these dumps (Guézennec et al. 2013). The following methodology is under development: (1) crossing several databases and information from BRGM archives, using selection criteria (waste quantities, metal content, waste age, metallogeny, mineralogy, process characteristics, etc.) to select wastes deposits of interest, (2) testing of on-site sampling methodology completed by lab analysis and (3) testing of pilotscale metal recovery techniques to assess the economic potential of the sites.

Three databases were used for the cross-analyses: ProMine Anthropogenic Concentrations (AC) databases (Cassard, 2012; Cassard et al., 2012), BDSTM (French Database of Sites and Mining Titles) and Dechminue.

ProMine is an ongoing EU project (2009-13), focused on 'innovative concepts and processes for strategic mineral supply and for new high added value mineral-based products'. A major goal of the project was to develop a Pan-EU GIS data management and visualisation system for natural and man-made mineral resources (http://ptrarc.gtk.fi/ProMine/default.aspx). The ProMine AC database focuses on major anthropogenic concentrations and includes data on volume or tonnage and metal content (i.e., possible presence of strategic metals). The total number of records in the database is 3,412 , of which 644 are located in France (Figure 5).

The BDSTM (Bouroullec et al., 2001) Database Sites and Mining Titles is used by the BRGM to identify mining sites that require environmental monitoring. This database includes environmental data but also data from mineral deposits, location of tailings and sometimes their tonnages and grades.

The Dechminue database (Thomassin, 2001) was developed during 2000 and 2001. This database is derived from a European project; it pinpoints 756 mining wastes sites in nine European countries (Bulgaria, Finland, France, Germany, Greece, Ireland, Portugal, Spain and Sweden) with their location, the period of activity, the type of process and the type of waste generated. 


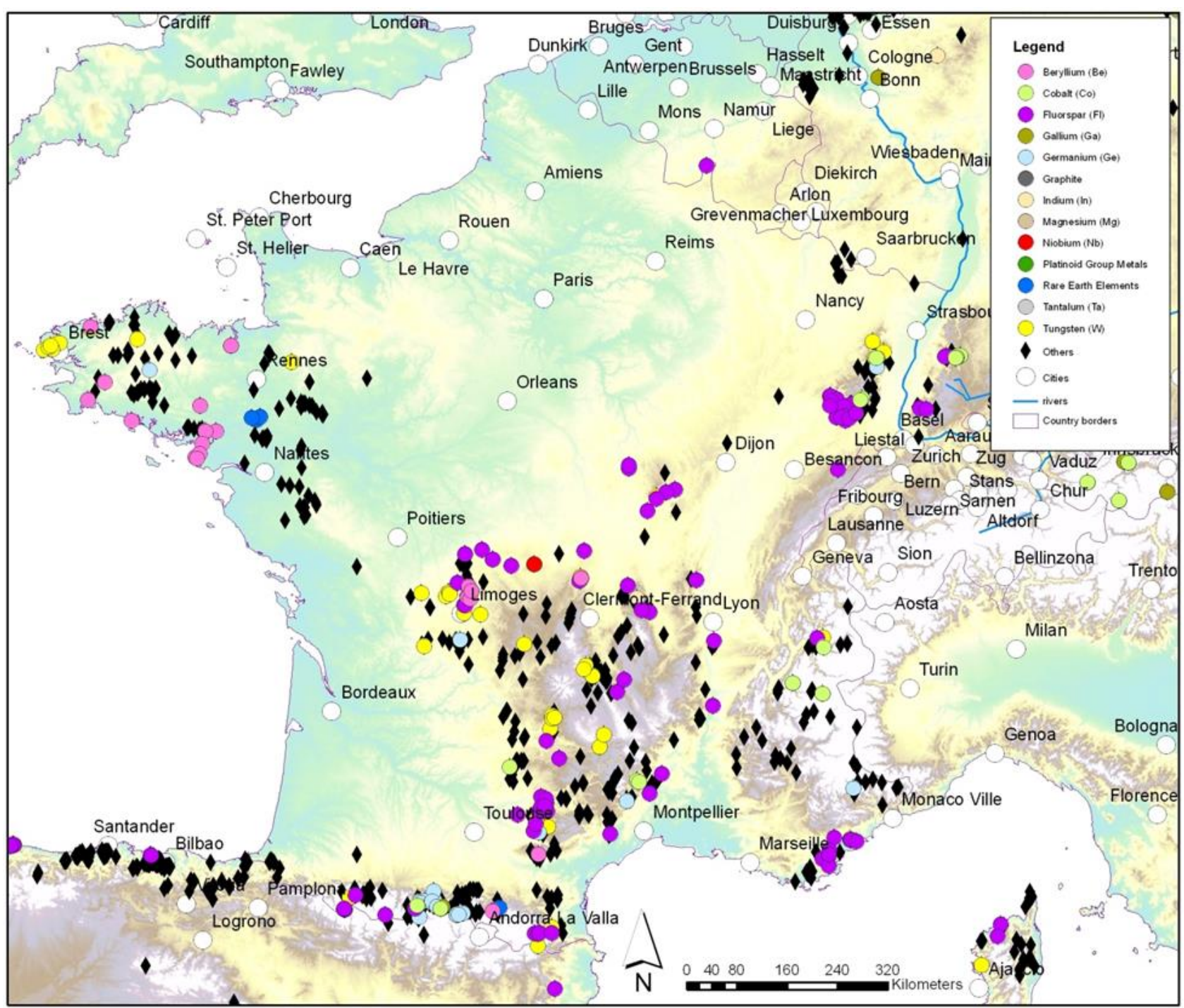

Figure 5 Past Mining and metallurgical sites in France (with major commodities) with mining wastes, extracted from the ProMine Anthropogenic Concentrations database (Guézennec et al., 2013)

The querying and cross-analysis of these databases led to the selection of 83 old mining sites. A last selection step based on expert opinion narrowed the list to 12 sites, corresponding to 70 million tonnes of mining waste. A further literature review was carried out on these 12 sites, including tonnages, ore residues concentration analyses, methods of forming deposits and ore processing methods that have been used in their operations.

The research programme focused at first on site 2 (described previously) for different reasons: (1) it provides a representative volume of $87,000 \mathrm{~m}^{3}$ of mining wastes with a possible presence of remaining silver especially as no flotation was performed; (2) the gravimetric separation handled at that time did not allow treatment of particles lower than $100 \mu \mathrm{m}$, which usually led to significant losses of silver; and (3) the BRGM is already involved in rehabilitation of this site.

On-site XRF chemical screening analyses were performed on surface and in depth (63 points for $44,900 \mathrm{~m}^{2}$ and 52 bulk samples). They were completed by laboratory analyses. Analyses and interpretation are still ongoing, but the first results demonstrate fairly consistent metal contents, with median concentrations of $\mathrm{Pb}, \mathrm{Fe}, \mathrm{S}$ and $\mathrm{Ag}$ of, respectively, 16,400 ppm, 24,400 ppm, 46,800 ppm and $43 \mathrm{ppm}$ (Guezennec et al. 2013). The preliminary results obtained from analysis of particle size fractions demonstrate enrichment in lead and silver for particles lower to $80 \mu \mathrm{m}$ and to a lesser extent for particles greater than $800 \mu \mathrm{m}$. 
Further analyses will be performed to design a process flowsheet for the recovery of silver (ICP-AES, X-ray diffraction and microscopic observations). The next step will be to implement a pilot to test this recovery. Other sites will be investigated using the same methodology.

In the end, the project will evaluate the economical balance of the mining waste reprocessing using a cost and benefits approach including the economic value of metals recovered, the cost of the reprocessing, the cost of the remaining materials' final and long-term safe disposal and the environmental benefit of this final disposal.

\section{$4 \quad$ Conclusions and perspectives}

The increase in demand (quantity and diversity) and metal prices has led to renewed interest in historical mining wastes, which can be considered as a potential source of base metals and critical metals.

One major difficulty regarding mining waste reprocessing concerns the quantification and distribution of elements and minerals on all scales, from the nano-scale to the macroscale, in space and time (for example, considering the oxidation of sulphide). Developing predictive tools and reliable, field-tested modelling of long-term mining waste behaviour is one of the greatest challenges. Such data and tools are needed to establish the recycling and reuse potential of these materials; geochemists and mineralogists have a significant role to play in this endeavour.

Similarly, innovation is needed to design mobile reprocessing units for the recovery of metal from mining waste deposits of small to medium size while taking into account their accessibility.

Any operation will require a cost-benefit approach to ensure its feasibility. This approach should take into account restocking the remaining mining wastes after their reprocessing:

- To ensure their long-term safe disposal so that they require minimal and, if possible, ultimately no monitoring, control and management of the closed mining waste facility.

- To prevent or at least minimise any long-term negative effects, for example, attributable to migration of airborne or aquatic pollutants from the mining waste facility. Thus the estimated costs for total worldwide liability associated with the current and future remediation of acid drainage are approximately US\$100 billion (Tremblay and Hogan, 2001).

- To ensure the long-term geotechnical stability of the storage facilities.

This new approach should consider the following strategy:

- Engage the operation if the economic value of the recovered metal is superior to the reprocessing costs and the final disposal of the remaining mining wastes.

- If not, include the long-term environmental and social benefits (especially regarding groundwater and surface water impact reduction) of the remaining materials' long-term safe disposal.

\section{Acknowledgements}

We thank P. Gentil, M Beaulieu, G. Bertrand, A. Fuentes, B. Lemière, M. Save and D. Niemiec for their help and contribution to this study. Valodem research project is fully supported financially by BRGM.

\section{References}

Achterberg, E.P., Braungardt, C., Morley, N.H., Elbaz-Poulichet, F. and Leblanc, M. (1999) Impact of Los Frailes mine spill on riverine, estuarine and coastal waters in southern Spain, Water Research, Vol. 33(16), pp. 3387-3394.

Blight, G. (2010) Geotechnical Engineering for Mine Waste Storage Facilities, CRC Press, Boca Raton, pp. i-xvii.

BRGM (1997) Les résidus miniers français: typologie et principaux impacts environnementaux potentiels, Rap. R 39503,83 p.

BRGM (2001) Management of mining, quarrying and ore-processing waste in the European Union, $79 \mathrm{p}$.

Bouroullec, I., Cottard, F., Dutartre, P., Fleury, L., Serrano, J.J. and Guérangé, J. (2001) Notice d'explication la base de données sur les anciens sites miniers de Midi-Pyréenées, BRGM/RP-51211-FR. 
Eurostat (2010) viewed June 2013, http://epp.eurostat.ec.europa.eu/statistics_explained/index.php/Waste_statistics.

Fosso-Kankeu, E., Mulaba-Bafubiandi, A.F., Mamba, B.B. and Barnard, T.G. (2011) Assessing the effectiveness of a biological recovery of nickel from tailing dumps, Minerals Engineering, Vol. 24(5), pp. 470-472.

Fourie, A. (2009) Preventing catastrophic failures and mitigating environmental impacts of tailings storage facilities, Procedia Earth and Planetary Science, Vol. 1, pp. 1067-1071.

Cassard, D. (2012) The use of standard exchange EarthResourceML in the ProMine project, in Proceedings 34th International Geological Congress, 5-10 August 2012, Brisbane, Australia.

Cassard, D., Bertrand, G., Maldan, F., Gaàl, G., Juha, K., Aatos, S., Angel, J.M., Arvanitidis, N., Ballas, D., Billa, M., Christidis, C., Dimitrova, D., Eilu, P., Filipe, A., Grazea, E., Inverno, C., Kauniskangas, E., Maki, T., Matos, J., Meliani, M., Michael, C., Mladenova, V., Navas, J., Niedbal, M., Perantonis, G., Pyra, J., Santana, H., Serafimovski, T., Serrano, J.J., Strengel, J., Tasev, G., Tornos, F. and Tudor, G. (2012) ProMine pan-European Mineral Deposit database: a new dataset for assessing primary mineral resources in Europe, in Workshop Notes Mineral Resources Potential Maps: a Tool for Discovering Future Deposits, 12-14 March 2012, Nancy, France.

Goktepe, F. (2005) Treatment of lead mine waste by a Mozley multi-gravity separator (MGS), Journal of Environmental Management, Vol. 76, pp. 277-281.

Grimalt, J.O., Ferrer, M. and MacPherson, E. (1999) Special issue: the mine tailing accident in Aznalcollar, Science of the Total Environment, pp. 242, 3-11.

Guézennec, A.G., Bodénan, F., Bertrand, G., Fuentes, A., Bellenfant, G., Lemière, B., D’Hugues, P., Cassard, D. and Save, M. (2013) Re-processing of mining waste: an alternative way to secure metal supplies of European Union, REWAS 2013: Enabling Materials Resource Sustainability, The Minerals, Metals \& Materials Society, pp. 231-237.

Högdahl, K., Jonsson, E., Troll, V. and Majka, J. (2012) The mineral treasure that almost got away: Re-evaluating yesterday's mine waste, in Proceedings 9th European Geosciences Union General Assembly, 22-27 April 2012, Vienna, Austria, Geophysical Research Abstracts 14:11387.

International Network for Acid Prevention (2011) viewed June 2013, http://www.inap.com.au/index.htm.

Johnson, D.B. and Hallberg, K.B. (2005) Acid mine drainage remediation options: a review, Science of The Total Environment, Vol. 338, pp. 3-14.

Juillot, F., Ildefonse, P., Morin, G., Calas, G., De Kersabiec, A.M. and Benedetti, M. (1999) Remobilization of arsenic from buried wastes in an industrial site: mineralogical and geochemical control, Applied Geochemistry, Vol. 14, pp. 1031-1048.

Kamradt, A., Borg, G., Schaefer, J., Kruse, S., Fiedler, M., Romm, P., Schippers, A., Gorny, R., Du Bois, M., Bieligk, C., Liebetrau, N., Nell, S., Friedrich, B., Morgenroth, H., Wotruba, H. and Merkel, C. (2012) An integrated process for innovative extraction of metals from Kupferschiefer mine dumps, Germany, Chemie Ingenieur Technik, Vol. 84(10), pp. 1694-1703.

Leblanc, M., Morales, J.A., Borrego, J. and Elbaz-Poulichet, F. (2000) 4500-Year-old mining pollution in southwestern Spain: longterm implications for modern mining pollution, Economic Geology, Vol. 95, pp. 655-662.

Morin, D. (1997) Le retraitement des résidus sulfurés de Kasese (Ouganda): un procédé de biotraitement supprime un point noir écologique et contribue de façon significative (5\%) et économique à la production mondiale de cobalt, Industry and Environment, Vol. 20(4), pp. 54-55.

Morin, D., Battaglia, F. and Ollivier, P. (1993) Study of the bioleaching of a cobaltiferous pyritic concentrate, in Proceedings International Biohydrometallurgy Symposium, 22-25 August 1993, Jackson Hole, Wyoming, USA, pp. 147-156.

Peek, E., Barnes, A. and Tuzun, A. (2011) Nickeliferous pyrrhotite - 'Waste or resource?' Minerals Engineering, Vol. 24(7), pp. 625637.

Reuter, M.A., Boin, U.M.J., Van Schaik, A., Verhoef, E.V., Heiskanen, K., Yang, Y. and Georgalli, G. (2005) The Metrics of Material and Metal Ecology, Harmonizing the Resource, Technology and Environmental Cycles, Elsevier, Amsterdam.

Tomassin, J.F. (2001) Déchets miniers Européens-Notice d'utilisation de la base DECHMINUE, issue des données du rapport 'Mining Waste Management ' de la DG Environnement- Rapport BRGM/51393-FR.

Tremblay, G.A. and Hogan, C.M. (2001) Mine Environment Neutral Drainage (MEND) Manual 5.4.2d: Prevention and Control, Canada Centre for Mineral and Energy Technology, Natural Resources Canada, Ottawa, 352 p. 